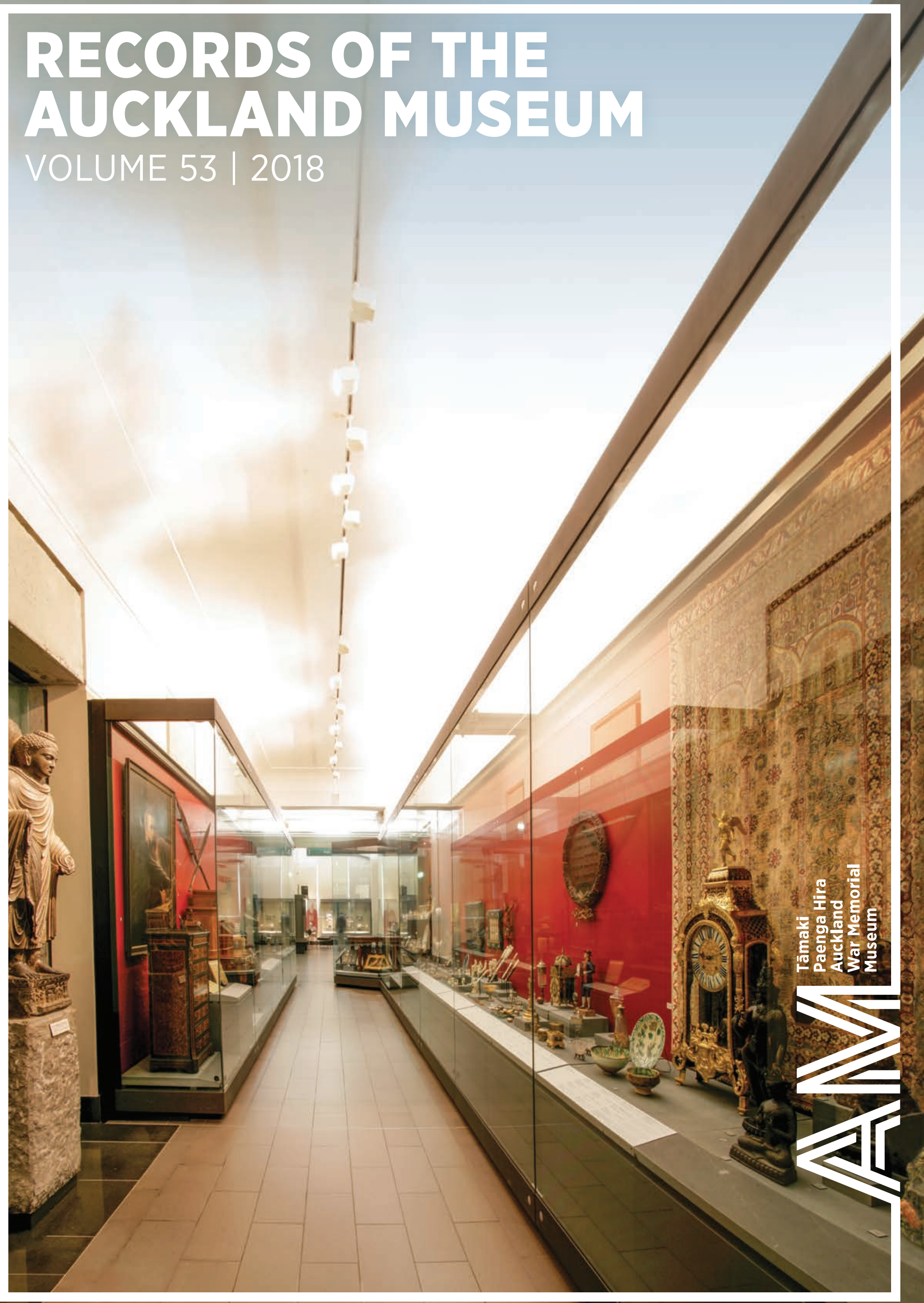




\title{
'Your list is certainly a formidable one': the Rev. A.H. Voyce and the Auckland Museum
}

\author{
Moira White Otago Museum
}

\begin{abstract}
The Auckland War Memorial Museum holds a large number of cultural objects, a collection of shells, and a group of butterflies, all collected by the Methodist missionary, Arthur Henry Voyce during his years as a Methodist minister in Bougainville in the period 1926-1958. His relationship with museums in New Zealand, and the background to the acquisitions is described.
\end{abstract}

\section{Keywords}

A.H. Voyce; Bougainville; Auckland Museum; Methodist missions; Otago Museum.

Voyce was born in Tasmania in 1899 but moved to New Zealand as a child with his family in 1907. He enrolled at Auckland's Trinity Methodist Theological College in 1923. Arthur married Beryl Haliday in the same month as his dedication - March 1926 - and the couple began what was to be over 30 years of missionary work on the island of Bougainville later that year.

A.H. Voyce amassed a very large collection of artefacts during his time on Bougainville, and facilitated collecting by other individuals and institutions. He was also an enthusiastic philatelist and conchologist. Voyce contacted the Auckland Museum in 1930, while he was in New Zealand during his first period of leave from the island, offering to place a quantity of material on loan there. The reply to this suggestion noted, "Your list is certainly a formidable one, and appears to be full of interesting articles, all of which, judging by the list, will be of good service here" (Auckland Museum to Voyce, 7 February 1930) and the conversation continued.

Voyce maintained his collecting, and contact with the Auckland Museum, through the 1930s and into the 1940s. The Australian Museum in Sydney, the Otago Museum in Dunedin, the Dominion Museum (now the Museum of New Zealand Te Papa Tongarewa) in Wellington, and Harry Beasley's Cranmore Ethnographical Museum in Kent also acquired material from him in those years. He is said to have provided much of the Rev. F. W. Brasher collection in the South Australian Museum, too (South Australian Museum and Hale: 204).

The Voyces were absent from Bougainville during the latter part of World War II. They returned immediately after, but collecting and museum contact seems to have been greatly reduced then. Arthur and Beryl retired to New Zealand in 1958.

\section{EARLY HISTORY}

An active member of his local Young Men's Bible Class group as a teenager, A.H. Voyce was recommended as a candidate for the ministry in the early $1920 \mathrm{~s}$. He enrolled at the Trinity Methodist Theological College in 1923 and offered himself for foreign mission work before finishing his course of study. Having completed three years at the College he was received on probation and at the fourteenth annual conference of the New Zealand Methodist Church, A.H. Voyce was dedicated to the work of the foreign mission in the Solomon Islands.

He married Beryl Haliday at the Methodist Collegiate Church in Grafton Road, Auckland on 17 March 1926. Beryl wore an ivy brocade crêpe de chine gown, and white georgette train with shell pink lining and silver lace. Her bouquet held white asters, dahlias, orange blossoms and maidenhair fern (Auckland Star, 26 March 1926: 12). Fellow students acted as Voyce's best man and groomsman. The couple sailed from New Zealand for Bougainville on the Mileusia (The New Zealand Methodist Times [NZMT], 14 August 1926: 14).

Named after (and by) the French 18th century circumnavigator Louis Antoine de Bougainville, the island of Bougainville was at that time part of the Mandated Territory of New Guinea, under the administrative control of Australia; a former part of Germany's colonial interests in the Pacific.

"It is a lonely and arduous outpost to which the Rev. A.H. Voyce and Mrs Voyce have gone", their colleague Allan Cropp wrote: "No finer work is being done today for God and humanity in the Pacific than by our devoted missionaries and their brave wives" (NZMT, 20 November 1926: 2). 


\section{ON BOUGAINVILLE}

Arthur and Beryl Voyce stayed initially with Cropp, who was appointed in 1921 (Luxton 1955: 111) at the Skotolan mission station while construction of their house was underway at Tonu, in the Siwai area to the south of the island. Voyce described visits to oversee the work: "We had to get the huge uprights and cross-bars cut from the bush... We got the post holes dug and the uprights in... The boys, under the guidance of the teachers, are to have the floor in, the roof on, and the walls up by the time we go again in about six weeks".

Maritime access was challenging. Voyce described an attempted landing:

\footnotetext{
"Mrs. Voyce and I went and got through safely. The next load capsized in a huge breaker, and a big safe and a horsehair bed and other things went floating off on the surface of the water... other things - a kerosene tin of rice belonging to the boys, 3 boxes and plants of ours, and a valuable portable gramaphone [sic] - which was proving such an asset and a blessing in our work - all went to the bottom of the ocean, never to be recovered. Naturally we were somewhat upset, but losses and trials of this sort are, I suppose, just some part of the missionary's life." (Open Door 5 (3): 3-6)
}

The Reverend and Mrs Voyce settled into their newly built house, planted a range of crops, started a school for local children, held church services and offered some medical treatments for the nearby population, such as dressing wounds, tropical sores and skin diseases. Beryl had attended a St John's course in Auckland but gained midwifery experience on the island.

In November, under the heading 'Cheerful in the midst of inconveniences', A. H. reported that in their first two months he had walked approximately $286 \mathrm{~km}$. $\mathrm{He}$ also noted the number of daily patients attending their clinic for treatment of sore, ulcers, boils and skin diseases had risen from 117 in their first week to 169 in the third, "It soon gets noised abroad that there is a free dressing of wounds at the Methodist Mission". He said they had already run out of crysophanic acid (which they mixed with kerosene to treat ringworm), and would appreciate the donation of an ear syringe. He added that as their bath and stove had not yet arrived Mrs Voyce was having to do all their cooking over a camp fire outside, and that they had run out of both dripping and butter (NZMT, 12 February 1927: 12).

A replacement for the mourned gramophone was received in 1927, at the end of which year there was a special request for cricketing gloves. He also suggested that gifts of calico and soap, beads, knives and mouth organs would be appreciated.

Writing of Bougainville in the 1930s, the American anthropologist Douglas Oliver noted that "Like the Marists the Methodists based their operations principally on stations, somewhat isolated from the indigenous communities, where youthful converts boarded, worked, attended school... the education included training in agriculture and industrial arts" (Oliver 1973: 117). This seems close to the situation Voyce described; Oliver's description may even be based on Tonu.

There were regular periods of furlough in New Zealand, and travel off-station also occurred for social and professional reasons. Soon after their arrival in 1926, the Voyces were best man and matron of honour at the wedding of the Revd Hubert Brown and Miss Irene Crespin at Numa Numa, on the island's east coast, on which occasion Mrs Voyce wore a dress of apple green crêpe de chine. A.H. attended the annual Methodist Synod meetings. At the Solomon Islands Synod in Roviana in 1928 he gave a trial sermon and was examined on his book list (NZMT, 9 February 1929: 12). In 1929 he described a fortnight's exploration into the 'wilds of the mountains' (NZMT, 21 September 1929: 10). The purchase of a surf boat, Te Oranga, earlier that year greatly reduced the time and effort involved in a trip to the Buin Police Post to collect mail and cargo: 20 hours by sea for a journey that was 80 miles (c. $129 \mathrm{~km}$ ) by road for the round trip (NZMT, 21 September 1929: 10). The rest of the world must have seemed a little less distant.

\section{CONTACT WITH AUCKLAND MUSEUM}

Arthur Henry Voyce was ordained in 1930. The couple (and their first child) were on leave in Auckland in the early part of that year, while the Reverend Tom and Mrs Dent lived at Siwai in their absence (NZMT, 5 April 1930: 15). Furlough involved a certain amount of deputation work and Voyce had vocational commitments, as well as enjoying time with family and friends. Beryl Voyce spoke to a number of Women's Auxiliary groups. Belshazzar Gina was still in New Zealand then, having been accepted as a candidate for the Methodist ministry in 1929. Gina was well known in Church circles, and he and Voyce visited the Taipowhenui pā near Hawera together. Following a welcome by the Revds R.T. Haddon and Piripi Rakena, both men spoke: Voyce about the mission work on Bougainville; Gina more personally about his father's conversion to Christianity and the effect of Christianity on his people (NZMT, 5 April 1930:10). Voyce also give an illustrated address at Te Awamutu in March, and spoke in Pahiatua, Makomako, New Plymouth, Takapuna and in Wellington, where he spoke to a Methodist Auxiliary meeting on the impact of Christianity on his mission district, and "...had many interesting curios to show, illustrating artistic handicraft among the people. A collection of beautiful butterflies also excited attention".

He took advantage of being in New Zealand to ask Sunday School Superintendents if they would donate materials for the Bougainville mission kindergarten teachers to use: picture cards, Plasticine, coloured papers, scissors and crayons; razor blades, rulers, whistles, pocket knives, belts, tennis balls or marbles (NZMT, 19 April 1930: 16). He also mentioned that a compass and a strong tent would make life more comfortable when he, Mrs Voyce and their baby were travelling in mountain areas; and that sets of slides for the magic lantern they had already received, would be well used. 
Voyce also made contact with the Auckland Museum It was during this period of leave. He wrote offering to place a quantity of material on loan there, and received an encouraging reply, "Your list is certainly a formidable one, and appears to be full of interesting articles, all of which, judging by the list, will be of good service here" (Anonymous, Auckland Museum to Voyce, 7 February 1930). The Museum arranged to have a Checker Express van call at the Voyce's Mt Eden address to uplift the collection. Gilbert Archey saw it when he returned from leave and wrote to tell Voyce he had shown a selection to members of the Institute Council, but suggested the return of some objects that he felt were already well represented there. A week later Voyce replied from Hamilton, asking for a list of the pieces that were to be retained by the Museum. He also mentioned he had more material with him, including a Fijian whale tooth necklace that he had obtained by exchange from Australia (Fig. 1). The two men discussed meeting when Voyce's deputation work in the North Island was completed.

The Rev. and Mrs Voyce left New Zealand in early May (NZMT, 17 May 1930: 14). Back in Bougainville, Voyce was eager to continue - to increase - his collecting activities. He was travelling more widely, negotiating passes in the Crown Prince Range which brought him into contact with the people of the Kongara, Kieta and Luluai Valley areas. At one point he reported that in nine days he had walked nearly $210 \mathrm{~km}$ in the Nagavisi and Baisi districts.
He described his collection of "stone implements from various islands... I have close on 200 here. Then there are some big things such as carved posts, wooden drums, etc which I would send if Captain Burgess could pick them up in Kieta - about May of 1931" (Voyce to Archey 24 October 1930). Burgess was then captain of the Southern Cross, the Melanesian Mission steamer. Not long after, Voyce wrote asking for "a few lines in writing to the effect that, should I require them [items from his collection at the Museum] any time in the future they will be made available. I don't anticipate requiring them for some considerable time, but it seems to be merely a business proposition to have this arrangement definitely in writing... Also, should I desire to insure the collection against all risks, can I do this through you?'(Voyce to Archey 26 October 1930)

The following year he wrote,

"I secured some fine old stuff from New Guinea hinterland recently, including one of the finest stone clubs on original handle I have ever seen. - also a couple of fine axes on original handles \& a very fine dogs' teeth \& shell breast ornament. Have also got some new things from other places, including an original stone fish from Buka \& the whole story of its use in the peoples' fishing culture. The stone fish I left in the Auckland Museum was a model (on a very large scale) of the original small ones, so sacred in the cult..." (Voyce to Archey, 21 May 1931). (Fig. 2)

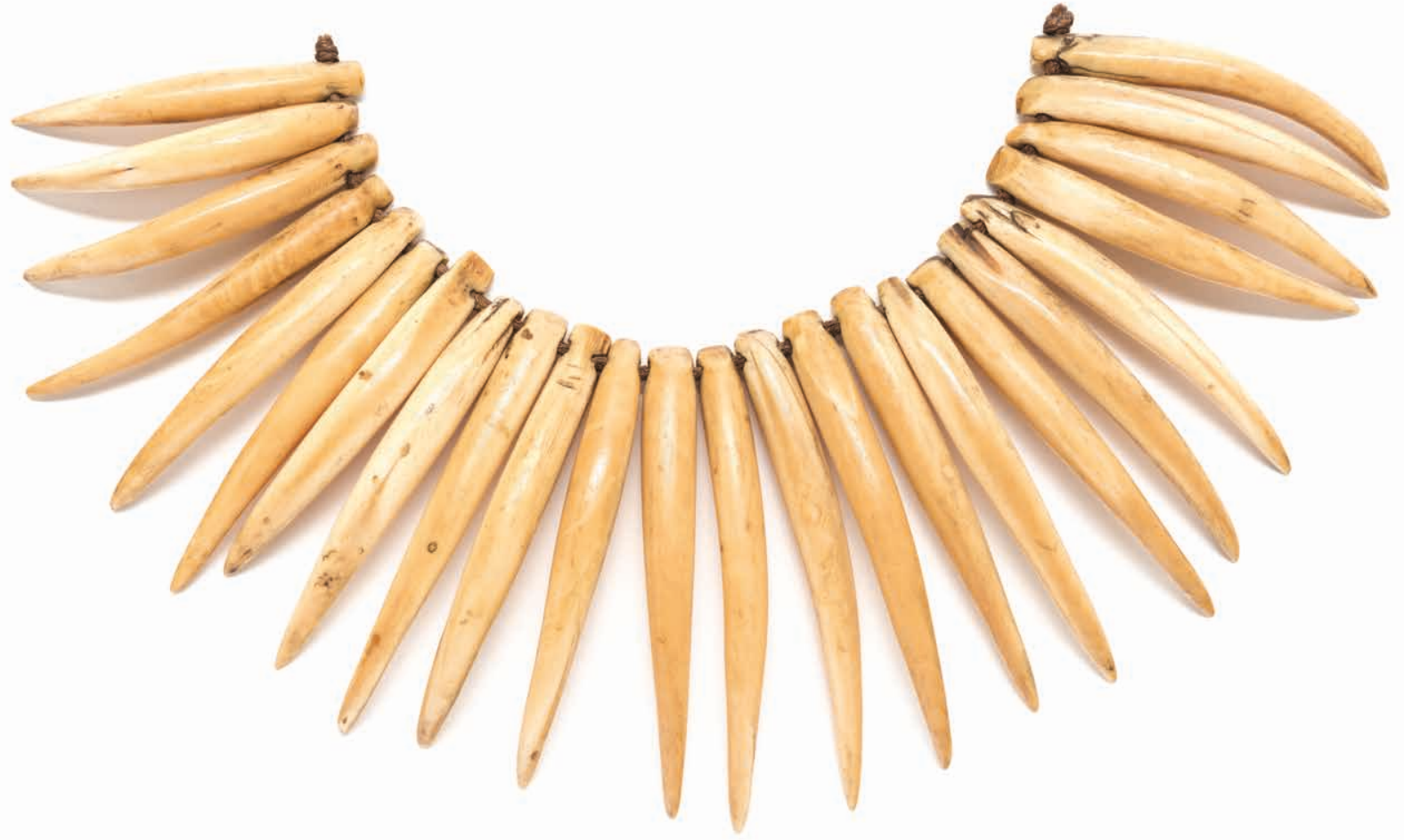

Figure 1. Wasekaseka. Auckland War Memorial Museum. 1930.16, 13661. 


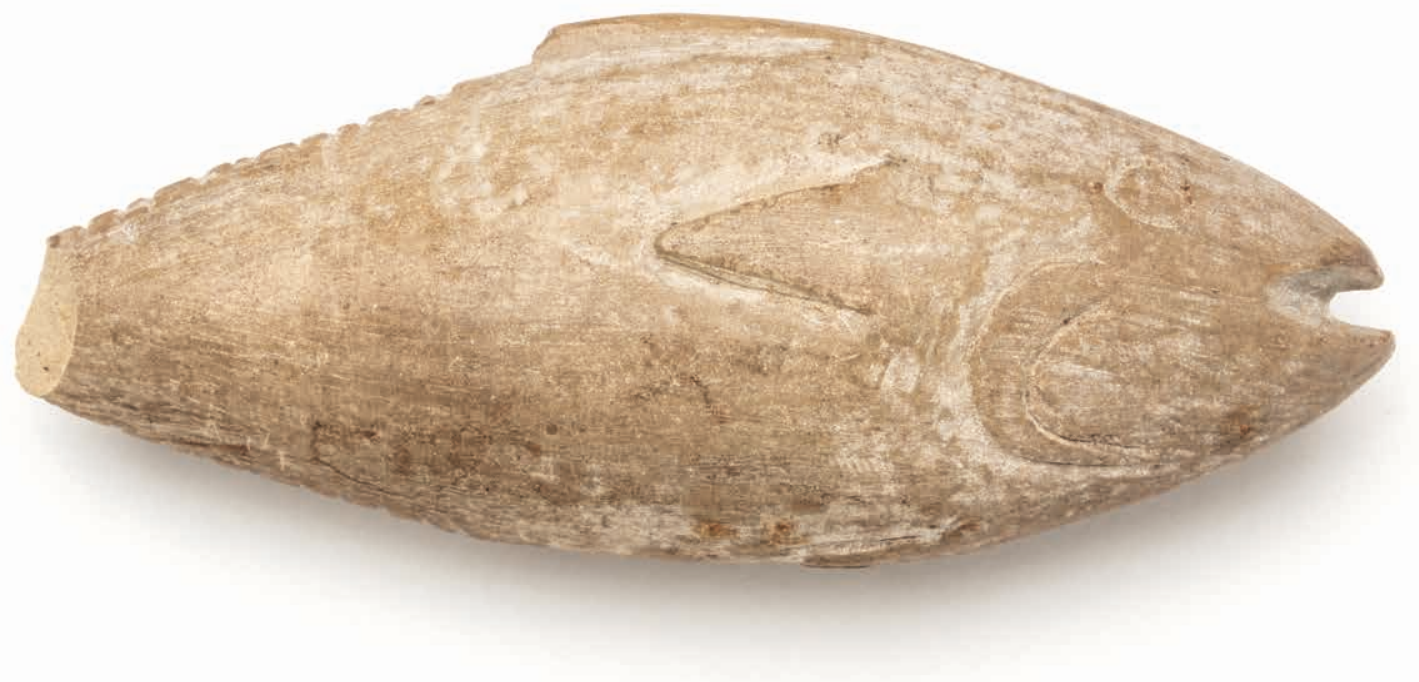

Figure 2. Atun. Stone fish, Petats Island, Solomon Islands. Auckland War Memorial Museum. 1934.145. 24195. Oxford anthropologist, Beatrice Blackwood, spent a year in the north of Bougainville over 1929-30, and seems to have had more contact with Cropp than with Voyce (1935: viii). She wrote that "the stone models of fish used in bonito magic (now sometimes replaced by the more easily manufactured wooden ones) are the only examples known to me of figures made of stone" (Blackwood 1935: 438).

The Southern Cross schedule did not include Kieta that year and Voyce said, 'I have not purchased the items yet - so I think it would be best to leave the matter in abeyance for a time. My own collection is of course rapidly mounting up - the stone implements are now going on for 800' (Voyce to Archey, 21 December 1931). He also offered to try to obtain particular items from the Solomon Islands or Papua New Guinea that Archey felt would be important for the Museum. Little specific guidance eventuated, Archey explaining 'it is really difficult for us to know here what to ask for, of course, there is such an amazing variety of articles made in Melanesia, and we have hardly sufficient detailed knowledge to be able to specify any one article. Generally speaking we are glad to get any genuine old article and would always be glad to receive examples of the commoner stone adzes from the different districts' (Auckland Museum to Voyce, 7 April 1932).

The Voyces' next period of leave was planned for late 1933. A.H. suggested to Archey that he deposit another large group of material at the Auckland Museum. In his reply, Archey mentioned the issues of storage space and the staff time involved in cataloguing, numbering and labelling. He raised the questions of tenure and possible acquisition:

"...we should like to be assured that the collection will remain for a long enough period for us to take advantage of it as comparative study material and for display. Of course we are hoping that it will, in the end, form part of our permanent collection as your gift..." He finished, "I therefore look forward with much interest to hearing your views on the ultimate permanent home of your collection" (Archey to Voyce, 31 March 1933).

Voyce responded that he was inclined to consider the suggestion if they could agree on the terms. He expressed a preference for the collection to remain intact. Despite Archey's tentative mention of a gift, Voyce was clearly interested in sale, rather than donation. "If I sell it", he wrote, "I will then be able to acquire during my further residence in New Guinea, a very much more extensive collection than I could otherwise do. Of course I always intended to continue to collect, but my resources are not large (I have only my missionary stipend - enough said) \& so the collecting would always be limited" (Voyce to Archey, 27 September 1933).

In New Zealand, two weeks of deputation work in South Canterbury was scheduled in September, followed by six weeks travelling in Otago and Southland. A lantern lecture titled 'Pioneering Amongst the Forest and Mountaineering Tribes of Bougainville' was given in the Temuka Methodist Church (Press, 19 September 1933: 6). Another at the Methodist Church in Rakaia attracted a large audience (Press, 16 September 1933: 5). Topics discussed at a well-attended lantern lecture in Ashburton included 'scenic attractions, climatic conditions, the products of the Islands, [and] difficulties encountered through grievances and superstition...' 


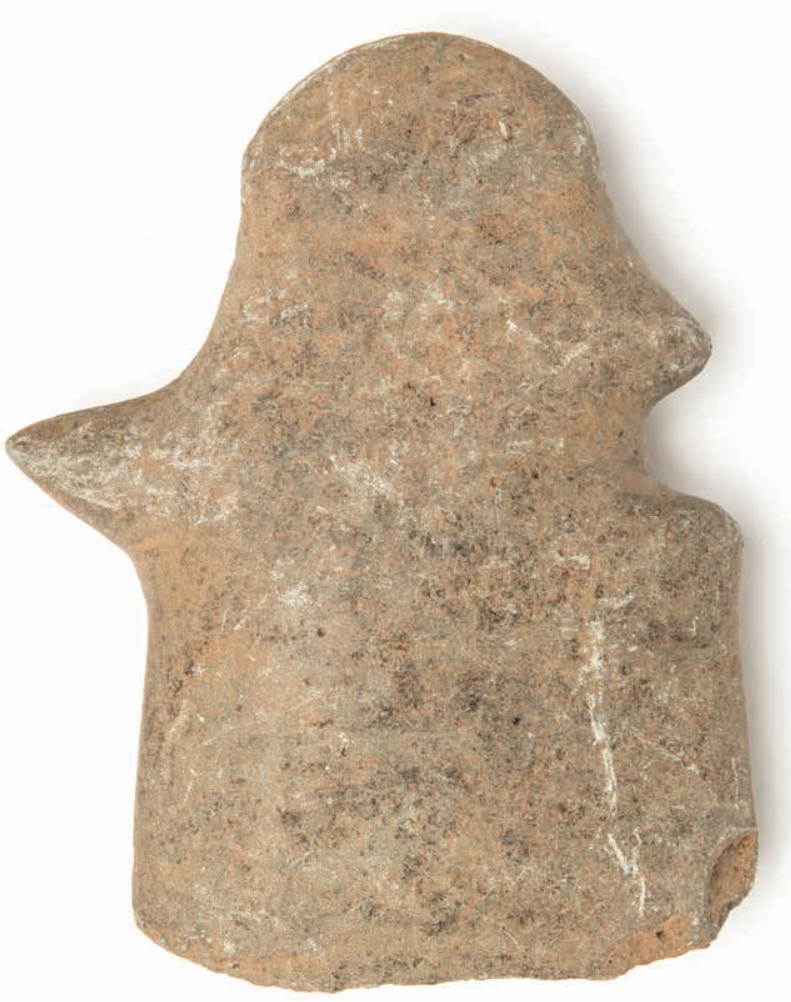

Figure 3. Adze. Roviana, Solomon Islands. Auckland War Memorial Museum. 1930.16. 38427.
(NZMT, 30 September 1933: 14) It closed with a display of 'specimens of native handiwork, shells, and butterflies' for sale: 'Good business was done' (NZMT, 30 September 1933: 15). His missionary meeting in Geraldine was described as 'luminous and informative'.

An advertisement headed 'Sale of Mission Curios' the following month (NZMT, 14 October 1933: 10) advised readers of the New Zealand Methodist Times that the Revd A.H. Voyce had brought with him to New Zealand 'large quantities' of basketry trays and mats (priced from between one and five shillings depending on size and style), plaited fibre work (including serviette rings), 'native necklets' of flying fox or opossum teeth (for one or two shillings) (Figs 4 and 5), 'wonderfully made' spear heads (five shillings each), and small, medium or large tropical shells, including cowrie or nautilus (from threepence to a shilling each). These items were being sold to raise money for the Missionary Society's Fund.

In Otago, Voyce delivered "a splendid address at a Foreign Mission anniversary service in Maheno", showing "numerous beautiful images of island scenes", after which "a wide range of native art and craft work" was exhibited (Otago Daily Times [ODT], 23 September 1933: 16). He spoke in Cromwell in early October. One apparent outcome of this engagement was the donation of a gramophone and thirty records to the Bougainville mission (NZMT, 9 December 1933: 14). At an evening lantern lecture in Palmerston the following month, 'Gorgeous tropical butterflies, beautiful shells, rare and intricate native

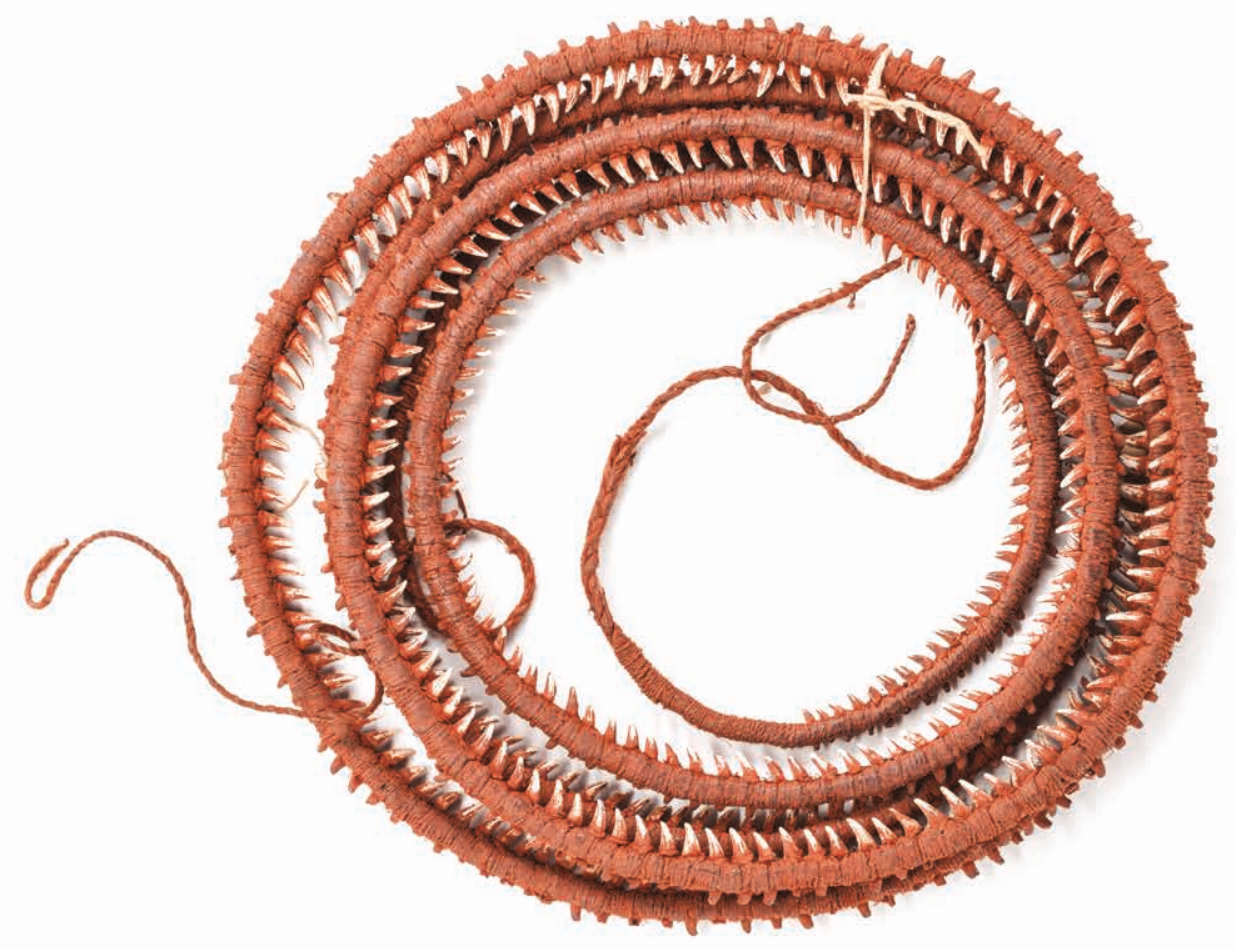

Figure 4. 'Flying fox teeth worked onto string and coloured with red pigment. Value of this currency f2'. Petats Island, Buka. Auckland War Memorial Museum. 1934.145. 20164. 


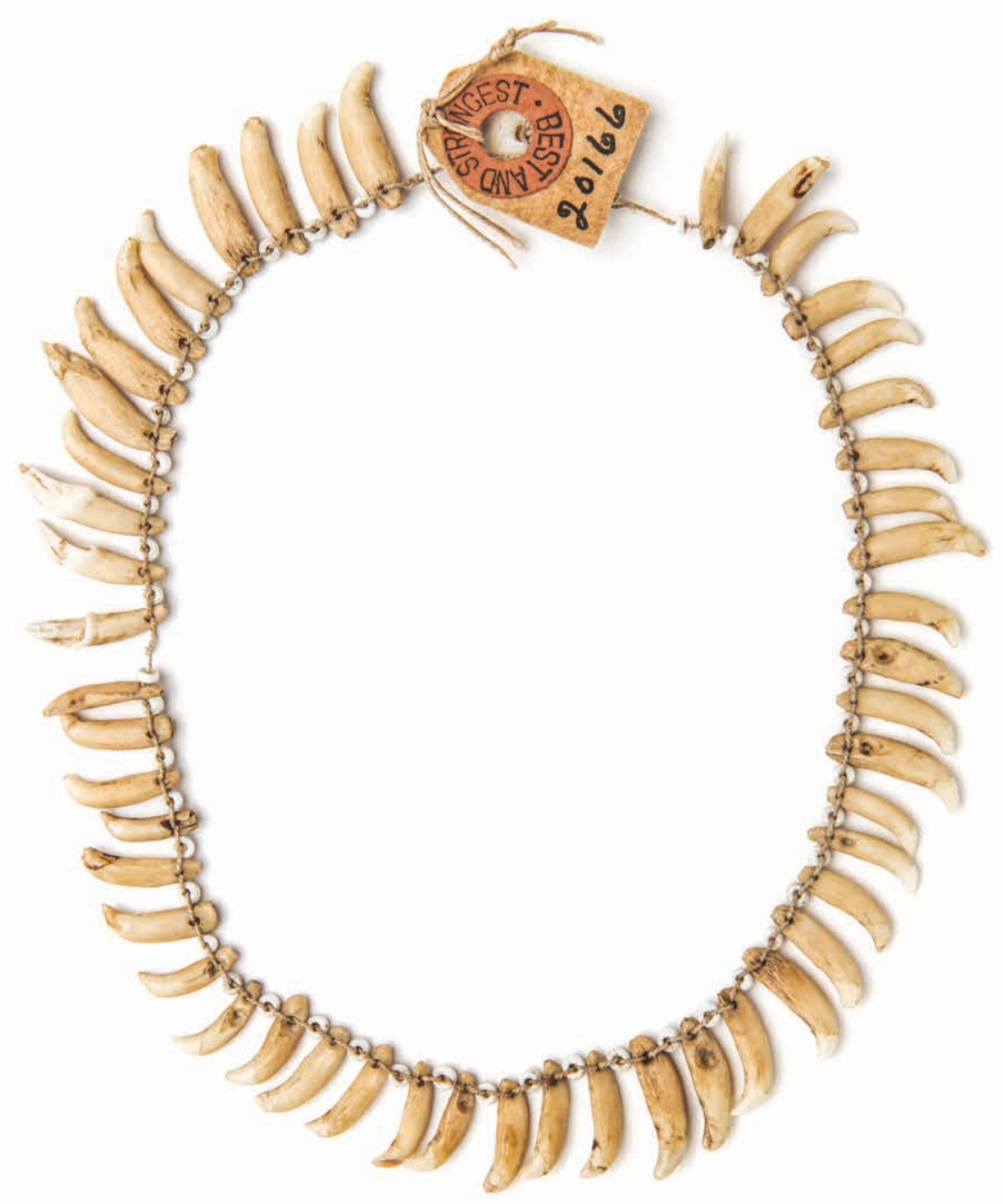

Figure 5. Neck ornament of teeth. Kunu Village, Siwai Distict, Bougainville. Auckland War Memorial Museum. 1934.145. 20166.

arts and crafts, the dreaded Kundu drum, and a hideous maneating crocodile, were among the novel sights shown' (ODT, 4 November 1933: 16). (Figs 6 and 7).

Later in November Voyce spoke at an 'at home' held in the Young Women's Christian Association club room in Christchurch, as part of an international week of prayer. He mentioned Bougainville's increasing economic importance due to gold and copra exports, and described the fauna as "grand and gorgeous, yet often repulsive" (Press, 17 November 1933: 2).

The Methodist Women's Missionary Union was held in Dunedin in 1933. Voyce attended and met H.D. Skinner of the Otago Museum while in the city. The encounter seems to have helped clarify his feelings on issues regarding his collection. He wrote to Archey soon after that Skinner,

“...showed me very proudly his Solomon \& Maori collections, (some classified in types something after the method I had hoped to pursue). I noted numerous articles on display, stone artifacts etc,
...\& I happened casually to mention the fact that I had brought home a collection of North Melanesian artifacts to the number of 1500 to 2000. He stood in amazement \& we talked much of stone implements. I told him that you had asked if I would consider its being acquired by purchase, by the Auckland Museum. He begged me to let him have a portion of the collection \& made a generous offer for a portion of it, without seeing any part of the collection. Of course I explained that it was impossible for me to treat for even a portion of the collection without first discussing the matter with you... He says that if they are able to acquire a portion, the collection would be open to me at any time for study purposes. Now, I merely mention this matter, so that in making an offer, you can please yourself whether you make an offer for it in whole or in part... Mr Skinner is going to give me much assistance on my return, in discussing classification of stone artifacts, etc ..." (Voyce to Archey, 27 September 1933) 


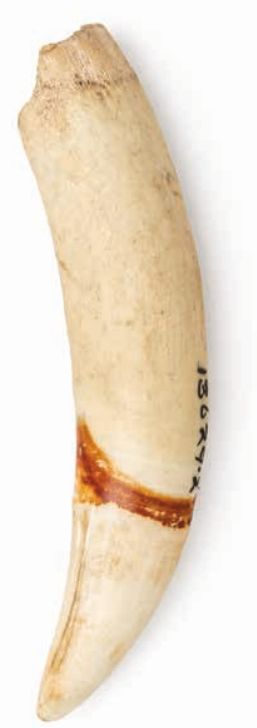

Figure 6. Kevi, crocodile tooth. Siwai District, Bougainville. Auckland War Memorial Museum. 1930.16. 13629.2
He preached at Methodist churches while in Dunedin including Dundas Street Methodist and the Cargill Road Methodist Circuit (Evening Star, 28 October 1933: 19).

Near the end of the year Voyce asked Archey directly if he was prepared to acquire his collection: "If you desire to make an offer, will you offer for the whole collection or will you have to consider a part being secured elsewhere? ... If it is a case of awaiting some Board meeting I would be glad if you would write briefly immediately, giving some indication of your opinion one way or the other, so that in the event of my early return to the islands I may have time to consider what I should best do in regards to the collection: (Voyce to Archey, 20 December 1933). This having first noted that he had received "an enquiry from the Cranmore Ethnographical Museum - Kent - England - but I don't propose to reply until I hear from you". (ibid.)

Shortly after, before he left New Zealand, he set a price and wrote agreeing to sell the material then on loan to the Auckland Museum to them for $£ 250$, on three conditions:

- that it be known as "the Rev A.H. Voyce collection, acquired by purchase";

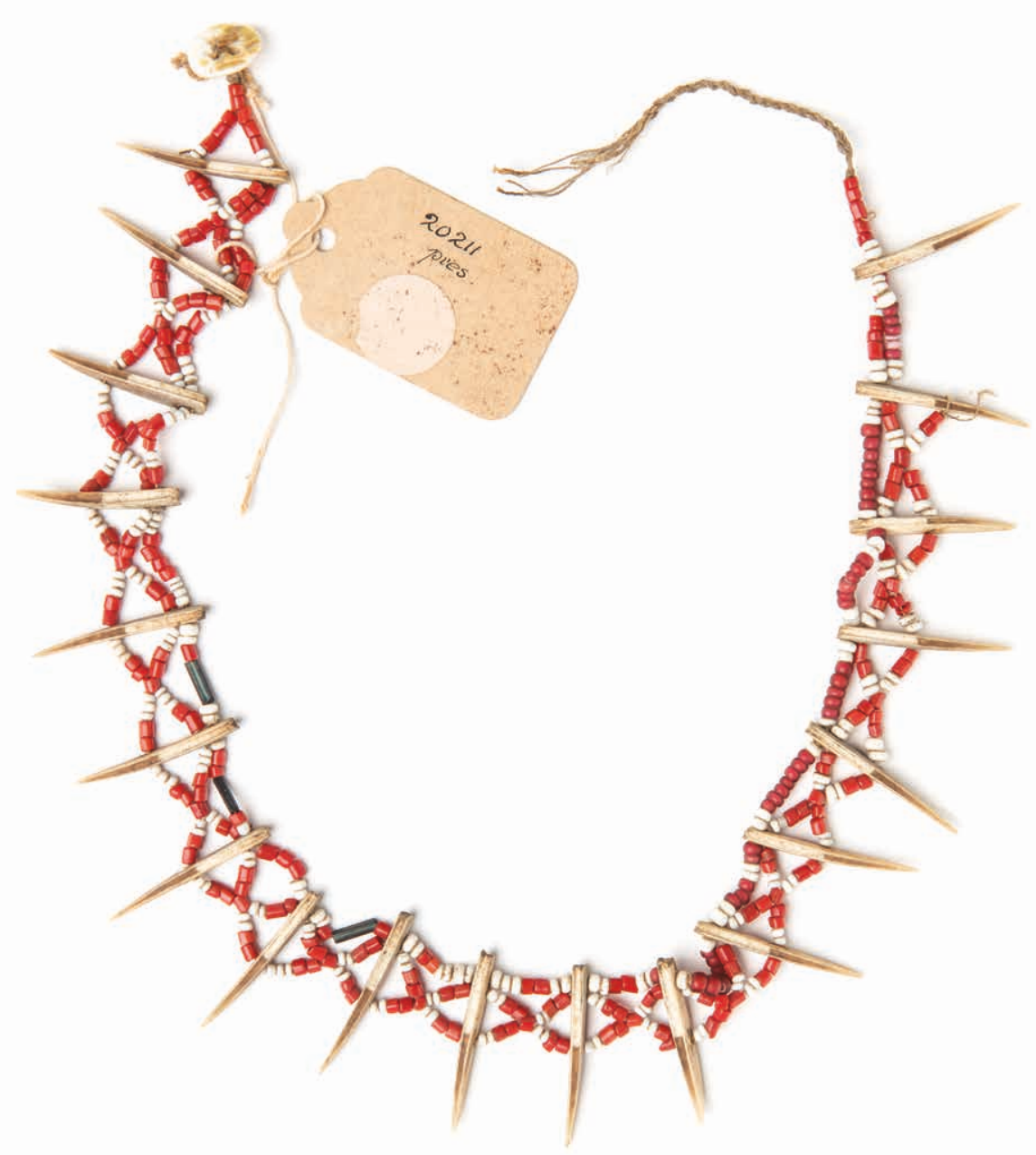

Figure 7. Neck ornament of sail fish teeth and glass trade beads. January 1931. Musiminoi, Siwai District, Bougainville. Auckland War Memorial Museum. 1934.145. 20211. 
- that he should have free access to it at any time for study or comparison; and

- that the Museum would supply him with a detailed listing of the collection when registration and cataloguing was completed (Voyce to Archey, 22 December 1933). The matter was with Archey for resolution, and he successfully sought external funding. Details of payment were agreed and a schedule finalised in 1934. Photographs of five items from Voyce's collection made up an illustrated page in the Museum's Annual Report for that year (Annual Report of Auckland Museum 1934: 9). Since the purchase was financed by another source, however, it was reported as an:

\footnotetext{
"important and generous gift... of a collection from Northern Melanesia presented to the Museum by a prominent citizen. This collection, which consists of over 2,000 specimens, comprises a wide range of articles, all carefully documented, among them being many types of ornaments, carvings and implements, and, in particular, a very extensive and compete collection of all types of stone adzes" (Auckland Museum 1934: 13).
}

The following year, the donor of an "extensive ethnographical collection from Northern Melanesia" in 1933 was named as Mr (later Sir) William Goodfellow,

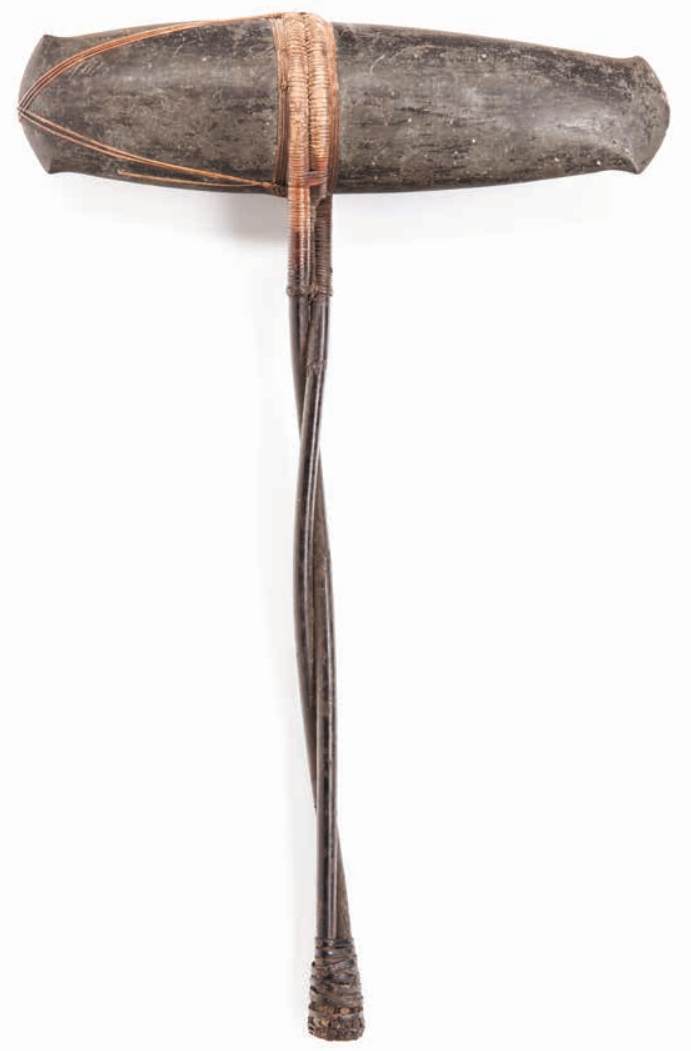

Figure 8. 'Hafted stone adze. ...beautifully shaped and flared at both ends. Polished, original handle.' Koaka, Kunua District, North Bougainville. Auckland War Memorial Museum. 1934.145. 20554. a Life Member of the Auckland Institute (Annual Report Auckland Institute and Museum 1935: 33). [accession number 1934.145].

Voyce, meantime, was still making contacts; still, apparently, anticipating the expansion of his collection. Skinner had given him a letter of introduction to Walter Reginald Brook [W.R.B.] Oliver, Director of the then Dominion Museum (now Te Papa Tongarewa Museum of New Zealand). Their first attempt at meeting didn't eventuate but early the next year Voyce wrote to Oliver (8 January 1934) from Buin to say he was sending "on deposit" some teeth necklets and bamboo combs "to serve as an introduction from here". He continued:

"I collect for several well known museums in NZ \& Australia, \& also for Cranmore Eth. Museum, but even so I am able to often secure duplicates to an extent not often desired by these institutions. Would your institute be agreeable to receiving genuine native arts, curios etc of Ethno. value \& interest, with place of origin, native name $\&$ all particulars given with the numbers, on deposit - with a view to purchase later... I write to know before purchasing much stuff, as I don't want too much left on my hands... Conditions would be that if you desired to receive a large lot on deposit, that you should pay shipping charges, $\&$ also that any big articles, too large for packing in cases etc, such as wooden gongs

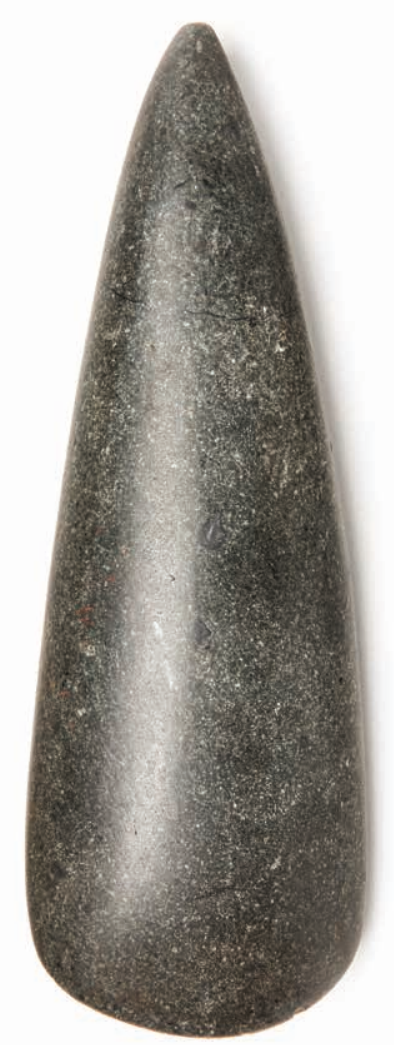

Figure 9. Kahaku, stone adze. Morone, Siwai District, District, Bougainville. Auckland War Memorial Museum. 1934.145. 20915. 
etc, would automatically become the possession of your museum, upon your defraying outgoing expenses". (ibid.)

Back in Bougainville, he wrote to Vic [Victor Frank, or V.F.] Fisher in Auckland, "I visited Aust Museum. They have very little Bougainville stuff. - Only a few adzes - ordinary type 1A. - \& only two kunua type 1 A. Very little other stuff. I was amazed at the smallness of their B \& B [Bougainville and Buka] section" (Voyce to Fisher, 5 March 1934).

Later in 1934, Voyce told Archey, he would be spending a year in Teop, further north (Voyce to Archey, 3 September 1934). Contact continued in the early part of 1935, with discussion of further possible acquisitions and Voyce's preparations for his paper, 'A Classification of the Wood-working Tools of Bougainville', to be delivered at the Fifth Science Congress of the Royal Society of New Zealand, in May (Anonymous 1936: 454). He also planned to present a classification of Bougainville kapkap (ibid.) The content for the former may have been drawn from a manuscript on the stone wood-working implements of Bougainville and Buka he offered to the Journal of the Polynesian Society [JPS] (Voyce to Archey, 24 January 1935) but declined, possibly because of its size and number of illustrations (Archey to Voyce, 22 March 1935). At the 1935 Solomon Islands Synod held in Buka, A.H. was elected Assistant Secretary.

In 1936, the Voyces moved again, to the southern coast of the main island, and began the work of establishing a new c. 150 hectare Head Station for south Bougainville at Kihili. They hosted 200 people for Christmas celebrations in December, which began with a 6 am service. Voyce planned to grow rice and peanuts, among other crops. With building of various structures and facilities underway he wrote in 1937, "work presses so hard one hardly knows what to do first, houses, roading, bridging, fencing, gardens." He was contending with his own physical limitations at the same time, having dropped a heavy log on his toe, crushed one thumb in a wire strainer, and suffered from patches of obstinate tropical ringworm.

In 1937 the annual Synod meeting was held at Sasamuga, Choiseul and at the end of that year the Voyces were again on furlough in New Zealand. As usual, A. H. travelled to fulfil his deputation obligations, and maintained communications with his museum contacts. He wrote to Walter Oliver at the Dominion Museum to let him know he would be attending the conference of the Methodist Church in February 1938, and hoped to be able to meet him then in Wellington. He exhibited a 'strange variety of articles of native craftsmanship' at one Auckland speaking engagement. In May he gave a lecture on the development of airfields in New Guinea to an Auckland Institute audience (New Zealand Herald, 26 May 1938: 22), and he was again negotiating the sale of a large number of artefacts to the Auckland Museum; this time his 'recent collection' of stone implements:

"You bought my last collection of about 1200 I think. This is a collection of more than twice that size - specialised - largely of Bougainville \& Buka - but containing many new types - also a comparative collection of many very unusual types from Choiseul \& New Georgia for comparison with B. \& Buka. Also some 40-50 very fine Mt. Hagen axes from New Guinea. All are catalogued as heretofore. I want $£ 360$ for the collection...

Also I have some books as under which I wondered if the Institute Library would be interested to consider for purchase..." (Voyce to Archey [6] May 1938)

The books included Guppy (1887), Ivens (1927), Meyer and Parkinson (1900), Beasley (1928), and Naven (Bateson 1936). Voyce was obviously familiar with the writing of collectors, missionaries, anthropologists and travellers in the area in which he lived.

By June he was reported to have completed a "very successful deputation itinerary of South Auckland, Auckland and Hawkes' Bay-Manawatu Districts" (NZMT, 4 June 1938:6). The two older Voyce children remained in New Zealand to attend school when A.H. and Beryl returned to Bougainville.

Matters were not finalised until the following year. Archey wrote:

\begin{abstract}
"It would hardly to right to say that I was disappointed, for no one appreciates more than I do the scientific value of all this localized material; but it does appear to me that there is a great deal of material of one type, more so, I must confess, than I had expected...
\end{abstract}

I may add that if the collection had included more of the articles other than adzes, that is to say, if the articles which I have been able to show the Council had themselves been able to make a wider appeal both to the members and, through our exhibition halls, to the public, the Council would, I am sure, be far more ready to pay the higher price and if, in future, you are able to send us on approval for purchase any articles of the type I have indicated, I am sure the Council would view the possible purchase in a liberal spirit. You will understand when I tell you that it is the long series of apparently quite uniform material, not all of it perfect, which fails to make an appeal to those who have the ultimate and important task of finding the money." (Archey to Voyce, 27 June 1939)

Nevertheless the purchase went ahead. 'Old friends' E. Earle Vaile and Mr Goodfellow were both credited with the gift of an 'important Solomon Islands collection' in the 1939-40 financial year (Annual Report of Auckland Institute and Museum 1940: 6, 33, 36; accession numbers 1940:101, 1940:102).Vic Fisher reported that as a result "Much time was devoted to the registration of a large collection of stone adzes from the Solomon Islands and New Guinea" (Annual Report of Auckland Institute and Museum 1941: 14). The Dominion Museum in Wellington, and the Otago Museum in Dunedin also purchased artefacts from Voyce in the late 1930s. 
Near the end of 1940 Voyce wrote to Fisher that he expected to be in New Zealand on furlough around July 1941, bringing with him "such articles as you have indicated a desire to have the offer of, e.g., shell ornaments, fish hooks, wooden carvings, pestles, mortars, fish traps or any kindred articles." He finished, "I have noted that you do not desire bows, arrows or spears, nor any further stone implements unless of new types" (Voyce to Fisher, 27 November 1940). Six items were purchased from Voyce in 1941 (Accession number 1941.157; L. Furey, pers. comm, 2018).

Voyce seems to have assumed that he, at least, would return to Bougainville after this period of leave. The advent of the Pacific War, however, meant the decision was taken out of his hands. Japanese forces landed on Bougainville while the Voyces were in New Zealand. During his enforced absence from the island, A.H. initially spent some time lecturing - to church groups, Rotarians, the Travel Club, and groups of American servicemen in New Zealand. For some of these engagements he apparently borrowed objects he had sold to the Auckland Museum, to use as illustrative material. The Museum wrote mid-year to remind him to return items they had lent him in March, as the "times of emergency necessitate frequent changes in the arrangement of our collections" (Auckland Museum to Voyce, 29 June 1942).

Early in 1943 he suggested the sale of his collection of bamboo boxes. These he said were "acquired 8 to 10 years ago. All are from Bougainville \& form an exhaustive collection of types $\&$ designs. They cost from $2 /$ - to $7 /$ - or $9 /-$ each... The collection is for sale as a whole \& is not open to breaking up..." (Voyce to Turbott, 12 April 1943). They were acquired the following year (accession no. 1944: 75). In May he spoke at a missionary rally to mark the forty-second anniversary of the founding of the Methodist Mission at Munda, New Georgia, in the 'stricken Solomon Islands', described as the Superintendent of Japanese Occupied Bougainville (Auckland Star, 20 May 1943: 8).

Not long after, however, he wrote of his almost immediate departure for Melanesia, saying he was "urgently recalled from the South Island by the Army Authorities examined \& passed yesterday \& I leave by plane in a day or two for the Pacific as Chaplain" (Voyce to Auckland Museum, 24 August 1943). Voyce served as a Chaplain with the New Zealand 3rd Army Division for a time in Vella Lavella, Solomon Islands, his familiarity with the area considered to be of use to the armed forces. He was also able to travel to meet church members on some of the other Western Province islands, and maintained contact with his Church colleagues in Auckland during these months. They reported he had visited the location of their former headquarters in the Munda area, on the island of New Georgia, including the site of their boat-shed, workshop and slip-way; but that all the vessels that had been left there were destroyed (NZMT, 22 January 1944: 5).

This account also seems to come from that time:

"On New Year's Eve, a native concert party, with Padre Voyce in charge, arrived at this camp, and in the afternoon, he conducted a thanksgiving service, which the natives of the village attended, bringing gifts of all kinds, such as mats, baskets, walking sticks, etc. That evening the concert party put on their show... when Padre Voyce announced that they would sing the "Hallellujah Chorus" I nearly fell off my seat with surprise... At the end of the concert, one of our lads acted as auctioneer and sold many of the articles brought down for the thanksgiving service. The bidding was quite spirited; an ordinary native mat sold for eighteen dollars, $£ 5$ 9s $6 \mathrm{~d}$ in New Zealand currency. Actually the mat was worth no more than about $9 \mathrm{~s} 6 \mathrm{~d}$. All the articles offered were sold for much more than their actual worth, but the lads were not thinking in terms of actual value. That was their way of contributing to the missionary work among the natives" (NZMT, 1 July 1944).

It seems Voyce continued to acquire objects during his time with the Army. Late in the year he wrote to Vic Fisher offering to sell a number of turtle shell pendants, cone shell pendants, tridcacna pendants, poata, shell currency and two pieces of 'native cloth' from 'the Vella Lavella, Kulambanga, Ranonga and Simbo areas of the New Georgia group of the Solomon Islands' (Voyce to Fisher, 4 December, 1944). Most were priced between one and five dollars, with annotated sterling conversion sums. Two separate 1944 purchases from Voyce are recorded; one of 273 items (accession no. 1944.14), the other of 63 items (accession no. 1944.75).

Voyce returned to New Zealand in early 1944; welcomed back at St Paul's, Remuera, on 27 February. In July of that year he gave a lecture titled 'The Native in the Pacific War Situation' at the Auckland Institute and Museum (New Zealand Herald, 20 July 1944). He also took advantage of the opportunity to research and write. In July, Methodist Times readers were informed that the Rev. Voyce had been granted three months leave on full pay to work on a book that would focus on 'our Mission work in the Solomons, but which will also include a geographical, historical and ethnological survey. After eighteen years' experience and close study of conditions on Bougainville and Buka and frequent contact with the British Solomons, Mr. Voyce's book should be authoritative and intensely interesting, especially to New Zealand and Australian Methodists' (NZMT, 1 July 1944: 2).

A.H. Voyce returned to Bougainville as soon as allowed - December 1945 (Luxton 1955: 197). His assessment of the situation at Kihili was, not surprisingly, depressing. As Japanese forces had occupied the area, it had been a target of the Allied offensive. He reported thousands of bomb craters full of stagnant water "and the Buin coast a litter of many hundreds of burnt-out Japanese trucks, motor-cars, tanks and other mechanical transport, gun posts, naval and anti-aircraft guns, planes and other things... Kihili... is a wilderness".

Beryl joined him a little later in the year, with a picnic set from the Ladies Auxiliary as part of her Auckland leaving gift. They and a number of other Methodist missionaries lived for some time on the west 
coast of the island at Cape Torokina, which had been the site of the first United States Marine amphibious landings in 1943. Voyce wrote in late 1946 of having sent a marquee down to colleagues who were building a station at Moisuru, near Kihili, which had access to a useful anchorage in Buin Bay (NZMT, 7 December 1946: 7). He also mentioned salvaging a two-engine barge and spoke longingly of a 'fine big refrigeration building' on the beach, both apparently left behind after the fighting.

The Voyces remained working in Bougainville for another decade, returning to live in New Zealand in 1958.

Arthur Henry Voyce died in Auckland in 1984. His funeral notice included the note: 'No flowers by request, but donations to the United Church, Bougainville, would be appreciated'. Beryl died nine years later in 1993.

\section{OTHER INTERESTS}

A.H. Voyce was also a shell collector and a keen philatelist. In the early 1930s he raised the subject of stamp collecting with Archey. Keen to obtain franked Solomon Islands stamps in good condition, he proposed posting a number of parcels to him at the Museum, from which Archey would carefully remove the stamps, with safe margins, and return them in his next letter to Voyce. A contributor to a postage stamp chat board in 2009 commented that 'For collectors of BSIP, a couple of Reverend A. H. Voyce covers are obligatory' (http:// www.stampboards.com/viewtopic.php?t=13132\&f=17).

In retirement he advertised for used WWII period envelopes from the Solomon Islands, and authored a number of Pacific postal history publications (Voyce 1966; Voyce 1971; Voyce 1974; Voyce 1981). A 1970s issue of Bougainville stamps (Voyce 1978) were illustrated with works from his own collection and, serendipitously, released on the Voyces' wedding anniversary.

He and his father worked together on Design Work as Shown on Bougainville Arrows and Spears (Voyce 1973). Deborah Waite's review astutely commented that the volume's primary value lay in 'the presentation of such a large quantity of weapons with geographic attributions and in the precise rendering of decorative details' (Waite 1978: 108). It also has a pleasing historic link. Voyce referenced the well-known Methodist missionary/collector George Brown's descriptions of Bougainville arrows (Brown 1908) and Melanesians and Polynesians (Brown 1910) in a letter, adding (Voyce to Scrivin, 31 October 1934), "I have a very varied collection of many scores of differing varieties of arrows ... some few with plain polished wooden points, and with decorated shafts, but the great majority being carved into very wonderful forms, many with holes of varying sizes through the heads, into which in times of fighting lighted grass or reeds were placed..., others again with forty and more reversely inserted barbs... others gaily decorated with coloured reeds".

Six years later he published Peacemakers: the story of David Pausu (Voyce 1979) which added to the documentation of Methodist church and mission history.

Voyce's name is also known in shell collecting circles and he published an article on Cox's cowrie (Voyce 1962).
As previously noted, he sold some species to aid mission fundraising. He also donated shells to the Auckland Museum at different times, the first with a group of corals and specimens of vegetable ivory, then collections of mollusca in later years (Annual Report of Auckland Institute and Museum 1931: 38; 1934: 45; 1935: 43).

He gave a number of butterflies to the Museum (Annual Report of Auckland Museum 1933: 19, 44) but there is little comment about their history and provenance. Newspaper accounts in 1930 and 1933 mention in passing that he showed tropical butterflies, shells and artefacts at talks given in New Zealand but do not elaborate.

\section{THE COLLECTION?}

The Revd Voyce was known in his lifetime to be a collector on an impressive scale. Douglas Oliver (1955) described him as an energetic collector of ethnographica. Thousands of artefacts left Bougainville at his instigation. A large but unknown number were possibly then-recently-made, for European purchase.

The Auckland Museum has 3452 artefacts purchased from A.H. Voyce. The molluscs and butterflies are additional. The Otago Museum has a similar number: there are more than 3500 object records linked to Voyce's name. As well as more than 1000 arrows, the collection includes adzes and axes, kapkap, bows, gourds, toys, pipes, women's clothing, belts, betel chewing equipment, baskets, bags and other containers, fish traps, combs, fishhooks, armlets, ceramic sherds, spears, ornaments, walking sticks, masks, clubs, a shield, bird snares, musical instruments, scrapers, wooden figures, barava fragments, sinkers, a pounder, tapa, and upi, molluscs and gastropods. More than 150 objects that Harry Beasley acquired from Voyce are now in the British Museum. In 1935 the Australian Museum bought 385 Bougainville - Buka artefacts from him: stone axes, body ornaments, bone implements, baskets, combs, aprons, spears and smoking pipes. Te Papa Tongarewa's Collections Online (https://collections.tepapa.govt.nz/ search/Voyce/results) shows 31 objects (including adze blades, armlets and armbands, belts, bags and biruka, combs and kapkap) and 12 specimens linked to A.H. Voyce. He also contributed some items to the Trinity Methodist Theological College Museum.

He collected, it seems, almost anything connected to the world he moved to in the 1920s. Some artefacts might have illustrated the different-ness of the foreign mission environment to a home audience. Others could bear witness to the changes Christianity had effected in the lives of the people among whom they lived. Well aware of this, Voyce described one particular neck ornament, asking 'Do you wonder why they brought this heirloom to me?' then answered, 'More and more as the years go by, are such things losing their value in the eyes of the people, no more, we hope, and believe, will tribal fighting take place in Siwai, for the Man of Galilee is making his influence felt in the cause of universal peace.' But it is his personal collection documenting minute variations in different object types; the multitude 
of items that reached various museums, the souvenirs and presents he arranged for visiting colleagues, which are more likely to be associated with him now. Personal collecting, and the enlistment of missionary assistance in the acquisition of cultural material and natural science specimens, by museums and other collectors, was almost commonplace in the early 20 th century. It had been so for decades when the Voyces went to Bougainville. Even so, the quantity of material he amassed is striking.

Where did it come from? Voyce had opportunities to collect in Bougainville that were available to few others in the first half of the 20th century. He was well known for walking great distances (Carter 1973: 181) during his first years on the island. He visited villages and other mission stations, relieved colleagues on furlough, attended Synod meetings in various locations, and travelled to larger centres for mail and supplies. Voyce visited commercial plantations on Bougainville in the course of his work and enjoyed the hospitality of their managers - a night's accommodation; a meal, a cup of tea or glass of chilled milk; offers of transport. He knew and sometimes travelled with men who had relatives or friends working on the plantations, and connections in other villages.

We have anecdotal hints at the relationship behind some pieces and though few, they indicate the breadth of his contacts and the contexts for his collection. The Auckland Museum collection includes some objects that came from named individuals (Figs 10 and 11).

He mentioned enquiring (successfully) for old stone implements when visiting a village to let them know the Mission could settle the teacher they wanted, there. He described a Thanksgiving service in which cash and curios both formed part of the collection (Voyce to Scrivin, 18 October 1934); the curios being sold (in that instance to staff) to add to the total. He mentioned going "into an inlet... leading eventually past a spot where the natives of that area meet at regular intervals to barter foods, etc. an old established native market" (Voyce to Scrivin, 30 July 1932). Although he physically unearthed some objects, he said that all the stone artefacts in his collection with the exception of perhaps 10 or 12 (which we found on clearing our station \& gardening)" had been purchased from local residents (Voyce to Archey, September 1933). He purchased and exchanged material with other collectors, for example Fig. 12. Dockets made out to A.H. Voyce from the Lutmis Store in Madang, record the sale of 14 Ramu axes for a total of $£ 2.15 .0$ and a wooden Sepik River figure for 3/6 in 1933.

Overall, one gains the impression that he was constantly open to possibilities. Did he fully understand the complexities of the gifts or exchanges he was part of? It is hard to know. We hear little of indigenous agency from him. He understood he had privileged access to the communities among whom he worked. His mission relationships meant he possessed, as he put it, 'a key of entry into almost every district'. He had some facility with the language himself and access to skilled interpreters. He mentions how eager villages are to have a teacher placed among them, and that the demand for injections and other medical services was great, but not the extent to which he considered that these were also part of the contexts in which his collecting took place.

One might also argue that his museum contacts effectively enabled Voyce to collect: financially and conceptually. One suspects he would have done so anyway, but they almost certainly augmented the scale. By purchasing material they freed up money for further acquisition. Provision of storage when material was on loan in the Auckland Museum - and research access after ownership changed hands - meant he was not burdened by those constraints and difficulties. Finally, they seem to have helped him to feel justified. When he introduced himself to WRB Oliver by saying he collected for several well-known museums, he was essentially offering credentials and claiming a collegial standing.

Voyce also actively increased the range of material culture items made (at least for sale; perhaps not for local use) in the areas in which he lived. He and Beryl introduced basket making to the Siwai area through the Tonu mission station. Beyond the usual means of church circulation, these were sold through a Bougainville trader and overtures were made to an Auckland outlet. When at Teop, he said they had "taught a lot of varying handicrafts, e.g. shells strung on strings as necklaces... sold ... at $1 \mathrm{~s}$ per string, occasional tables, walking sticks of very old coconut wood, some inlaid with shell, others carved tops, others with ivory nut tops and others just plain polished sticks, serviette rings of plaited pandanus and wild black banana fibres etc, etc," (Voyce to Scrivin, 18 October 1934). Parallels between this and the list of items sold for fundraising purposes (NZMT, 14 October 1933: 10) indicate that the material advertised for sale at his meetings in New Zealand, and at the 1944 concert party described above, were largely of contemporary manufacture. How much of the material sold to museums or circulated through other transactions was of this ilk is unclear, and possibly not well documented. Geographical provenances are attached to a large number of Voyce collection items, but that is not of course an indication of age. There are, for example, quantities of seemingly little-worn fibre items.

The scientific corollaries of collecting appealed to Voyce. Aware that it would enhance the interest and research value of objects he amassed, he noted local language names, recorded localities, sought to identify variations of a form or design. He developed an interest in folklore and legends, and joined the Polynesian Society. Madden, at the Cranmore Museum (possibly at Beasley's behest), organised Voyce's nomination as a Fellow of the Royal Anthropological Institute, with local correspondent status.

During periods of leave he spent time working with material he had deposited in the museum. Planning to publish, he asked museum staff for sketches, diagrams, photographs, measurements, weights and geological determinations. Classificatory systems appealed. As Gardner (2006) noted for his 19th century predecessors, morphology and geographical location; presence or absence interested him. He told Vic Fisher how helpful for his formulation of tool types he had found it to be able to see all the relevant material together in one place. 


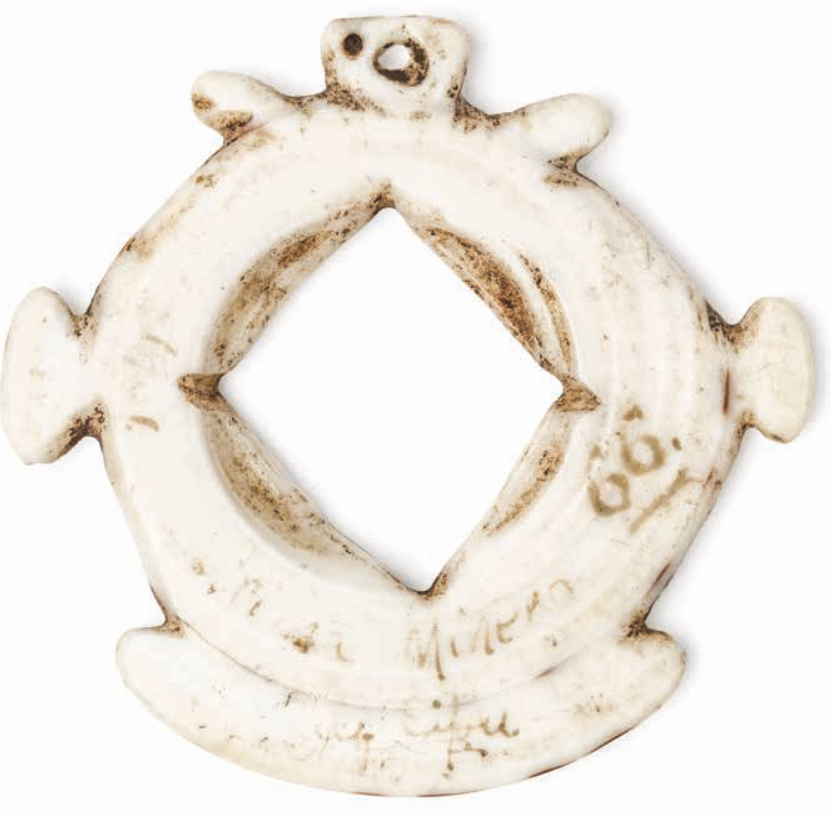

Figure 10. 'Kesi, shell breast ornament. from Chief Sipiu.' January, 1931. Sirima, Mihiro, Siwai District, Bougainville. Auckland War Memorial Museum. 1934.145. 20189.

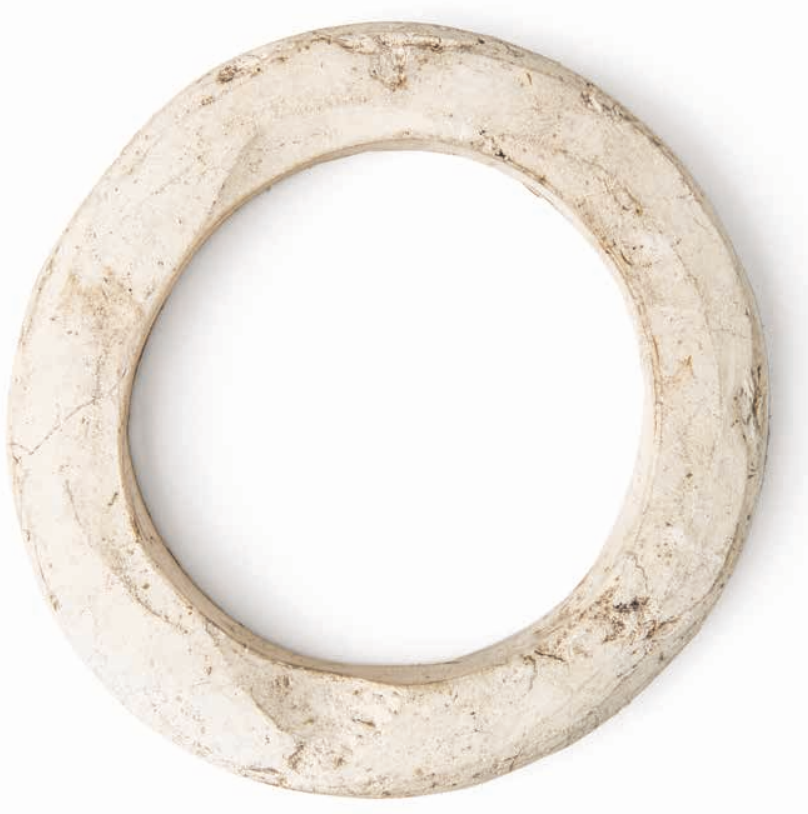

Figure 12. Poata, shell ring. Dug up at Kindu by Rove, December 1930. Kindu, Roviana, New Georgia. Auckland War Memorial Museum. 1934.145. 20204.

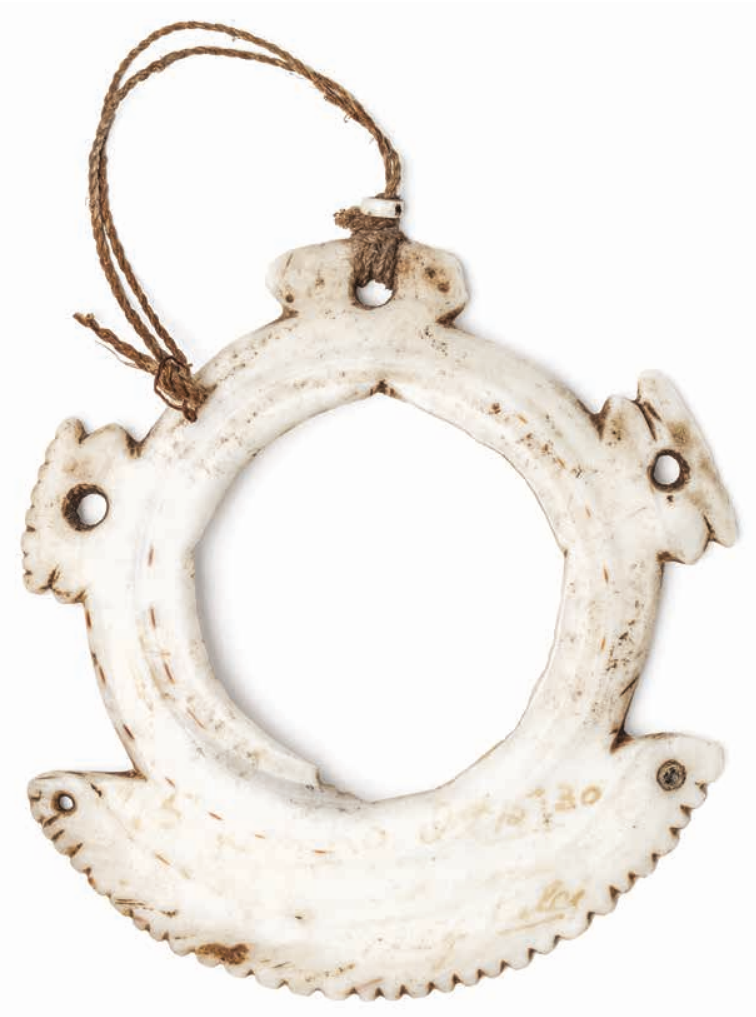

Figure 11. 'Kesi, shell breast ornament from Chief Putei.' October, 1930. Kahiko, Siwai District, Bougainville. Auckland War Memorial Museum. 1934.145. 20194.

'Remember how our backs used to ache when we were working on the stone implements?' he asked. Skinner encouraged his interest in writing. He lent him books by Douglas Kennedy, and Gladys Reichard (1933), and singled out Te Rangi Hiroa's Samoan Material Culture (Buck, 1930) as a model.

Despite all this, Voyce's publications are primarily philatelic. The National Library of Australia holds copies of school exercises (Voyce 1931) and hymns that Voyce translated into Motuna (Voyce 1932). The Auckland Museum Library holds a manuscript copy of a draft paper on wooden drums from Bougainville (Voyce ms). H.D. Skinner expressed confidence that it would be of interest to the JPS but encouraged him to consider making the varied articles he was contemplating, chapters in a single book (Skinner to Voyce, 18 December 1933). It is unclear whether the manuscript Voyce was working on in 1944 stemmed from that; if it was one of those he did publish; or if it was uncompleted.

As Lucie Carreau (2010) perceptively wrote when discussing Harry Beasley, it is often unclear when a collection starts or gains formal recognition. As with Beasley's, the inception of the Voyce collection is vague. Indeed, can every item that passed through his ownership be considered part of his collection? Its full extent is ambiguous for a number of reasons including the multiplicity of people whose own collecting he facilitated. While conventions vary between institutions, 


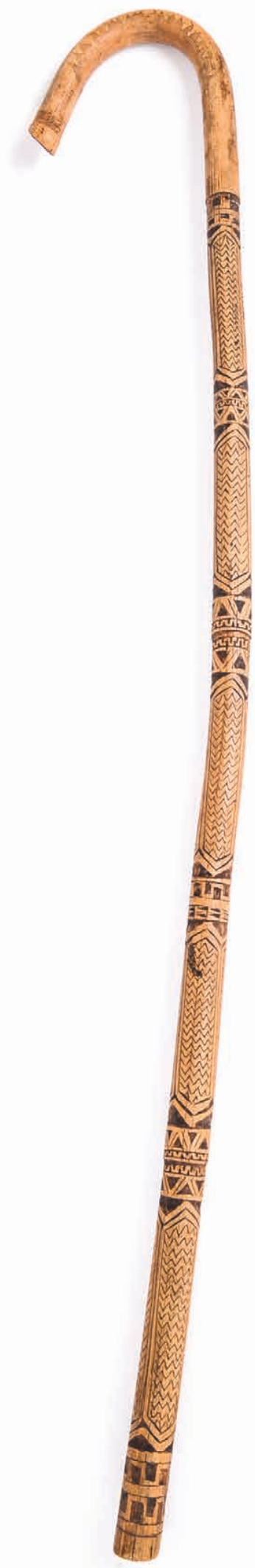

Figure 13. Walking stick. Otago Museum, Dunedin. D39.1891. at the Auckland Museum the appropriate courtesies of acknowledgment meant that at the time of acquisition, Voyce was less publically reported in connection with the collection than were Sir William Goodfellow or E. Earle Vaile, the donors.

A question to add is when does a collection end? Voyce's first sale to the Auckland Museum seemed to mark a finite group of material with some personal meaning to him. Yet once the transaction was complete, acquisition started anew, or continued. As each group was parted with others seemed to come into view.

To what extent can his collection be said to represent a way of life in Bougainville? We might wish we knew more of the cultural context for the objects he acquired, and more details of the relationships and transactions that took place between Voyce and the original owners. What role did he see for the mass of material culture that he helped to leave Bougainville, play in New Zealand, Australian and European museums?

The Voyce collection also invites conjecture about the role of these objects in his own identity, to the world of the museum associates with whom he was in contact for a decade or more; and their impact on the public who have seen and thought about them since they left Melanesia.

\section{ACKNOWLEDGEMENTS}

Grateful thanks to Louise Furey and to Kolokesa Māhina-Tuai, also to Fuli Pereira, and Zoe Richardson, all of Tamaki Paenga Hira Auckland War Memorial Museum; Logan Mecalfe, Australian Museum; Cynthia McKenzie, Methodist Church Archives; Jennifer Twist, Te Papa Tongarewa Museum of New Zealand; and Christopher Pugsley.

\section{REFERENCES}

Anonymous, 1936. Minutes and Proceedings of the Fifth Science Congress of the Royal Society of New Zealand. Transactions and Proceedings of the Royal Society of New Zealand 36: 451-6

Annual Report of the Auckland Institute and Museum for 1930-31. Auckland.

Annual Report of the Auckland Institute and Museum for 1932-33. Auckland.

Annual Report of the Auckland Institute and Museum for 1933-34. Auckland.

Annual Report of the Auckland Institute and Museum for 1934-35. Auckland.

Annual Report of the Auckland Institute and Museum for 1939-40. Auckland.

Annual Report of the Auckland Institute and Museum 1940-41. Auckland.

Bateson, Gregory, 1936. Naven: A Survey of the Problems suggested by a Composite Picture of the Culture of a New Guinea Tribe drawn from Three Points of View. Cambridge University Press.

Beasley, H.G., 1928. Pacific Island Records: Fish Hooks. London: Seeley, Service \& Co.

Blackwood, Beatrice, 1935. Both Sides of Buka Passage. Oxford: Clarendon Press. 
Brown, George, 1908. George Brown, D.D. Pioneermissionary and explorer, an autobiography; a narrative of forty-eight years' residence and travel in Samoa, New Britain, New Ireland, New Guinea and the Solomon Islands. London: Hodder and Stoughton.

Brown, George, 1910. Melanesians and Polynesians: their life-histories described and compared. London: Macmillan \& Co.

Buck, Peter Henry, 1930. Samoan Material Culture. Honolulu: Bernice Pauahi Bishop Museum.

Carreau, L., 2010 'Becoming 'Professional': From the Beasley Collection to the Cranmore Ethnographical Museum. Journal of Museum Ethnography 23: 41-55. Accessed 10 July 2018, Stable URL: http:// www.jstor.org/stable/41416854

Carter, George, 1973. A Family Affair. Auckland: Institute Press.

Gardner, Helen, 2006. Gathering for God: George Brown in Oceania. Dunedin: Otago University Press.

Guppy, H.B., 1887. The Solomon Islands and Their Natives. London: Swan Sonnenschein, Lowrey \& Co.

Ivens, Walter, 1927. Melanesians of the South-east Solomon Islands. London: K. Paul, Trench, Trubner.

Luxton, C.T.J., 1955. Isles of Solomon. A Tale of Missionary Adventure. Auckland: Methodist Foreign Missionary Society of New Zealand.

Meyer, A.B. and R. Parkinson, 1900. Album of Papua types II. Dresden: Stengel \& Company.

Oliver, D., 1955. A Solomon Island Society. Harvard University Press.

Oliver, D., 1973. Bougainville a personal history. Melbourne University Press.

Reichard, Gladys, 1933. Melanesian Design, a study of style in wood and tortoiseshell carving. New York, Columbia University Press.

South Australian Museum and H.M. Hale, 1956. The First Hundred Years of the [South Australian] Museum 1856-1956. Adelaide.

Voyce, A.H., [1931] Solomon Islands school exercises, English-Motuna. Wellington: Wright and Carman Printers.

Voyce, A.H., 1932. [Hymns]. Kieta Bougainville: Methodist Mission.

Voyce, A.H., 1962. Hunting Cypraea coxeni in the Solomon Islands. The Cowrie 1 (4): 56-8.
Voyce, A.H., 1966. The Postal History of Barakoma Airfield. Melbourne: Hawthorn Press.

Voyce, A.H., 1971. New Zealand Registration Markings. Auckland: Postal History Society of New Zealand.

Voyce, A.H., 1973. Design Work as Shown on Bougainville Arrows and Spears. Rabaul: Trinity Press.

Voyce, A.H., 1974. Bougainville Police Runner Mails. Masterton: R. Startup for the Postal History Society of New Zealand.

Voyce, A.H., 1978. Bougainville Art: the planning of a set of new stamps. Coromandel: Ponwinkle Publications.

Voyce, A.H., 1979. Peacemakers: the story of David Pausu and the United Church of South Bougainville. Auckland, Wesley Historical Society.

Voyce, A.H., 1981. A Place in the Sun. Coromandel: Ponwinkle Publications.

Voyce, A.H. The wooden drums and drumming of the Motuna people, South-western Bougainville Island, Northern Solomons, Mandated Territory of New Guinea. Auckland War Memorial Museum MS-632.

Waite, Deborah B., 1978. Review: Voyce, H. M. Design Work as shown on Bouganville Arrows and Spears. Pacific Studies 2(1): 107-8.

Unpublished sources

Correspondence between A.H. Voyce and staff of the Auckland Museum is held at the Auckland Museum Library:

Between 1931 and 1935 (incl.), correspondence between Archey and Voyce, between Fisher and Voyce, and between Voyce and the Auckland Museum, is held at Auckland War Memorial Museum MUS-95-43-20.

Between 1938 and 1945 (incl), correspondence between Archey and Voyce, between Fisher and Voyce, between Turbott and Voyce, and between Voyce and the Auckland Museum, is held at Auckland War Memorial Museum MUS-95-43-21

Correspondence between Voyce and Scrivin is held at Alexander Turnbull Library Micro-MS-Coll-08-0935

Correspondence between Voyce and Oliver is held at Museum of New Zealand Te Papa Tongarewa: MU000002-064-0

Moira White, Otago Museum, Dunedin. Moira.White@otagomuseum.nz 
